\title{
In Silico Analysis of Physical-Chemical Properties, Target Potential, and Toxicology of Pure Compounds from Natural Products
}

\author{
Purnawan P. Putra*, Annisa Fauzana, Henny Lucida \\ Faculty of Pharmacy, Universitas Andalas, Padang, West Sumatra, Indonesia \\ Submitted 26 February 2020; Revised 6 July 2020; Accepted 14 August 2020; Published 30 October 2020 \\ *Corresponding author: purnawanpp@phar.unand.ac.id
}

\begin{abstract}
Several studies have shown that pure compounds from west sumatera medicinal plants have beneficial therapeutic effects so that they are potential candidates for active pharmaceutical ingredients (API). Andalas Sitawa Fitolab has been able to produce 10 pure isolates. The development of a new drug candidate requires an in silico study to predict physicochemical properties, potential target, and toxic properties. The purpose of this study was to initially screen the structure of candidates to predict the potential the compound as an API by using big data and machine learning. The chemical structure were analyzed using software and servers. The Software used was Marvin Sketch, QSAR Toolbox, Swiss Potential Target and ChemBioDraw. Results showed that $\log \mathrm{P}$ of compounds revealed in a range of -0.54 to 4.64, Polar Surface Area (PSA) in range of 20.23 to 315.21. Asiaticoside did not meet Lipinski's rules. Compounds with high potential hazard were catechin, curcumin, andrographolide, asiaticoside deoxyelephantopin, ethylmethoxycinnamate, alpha-mangostin and piperine. The compounds such as curcumin, alpha mangostin, plumbagin, and piperine were predicted to have spesific target proteins. This study concluded that asiaticoside compounds have a high potential hazard, if it was developed as an API.
\end{abstract}

Keywords: analysis of physical-chemical properties, in silico, pure isolate, toxicology

\section{Analisis Sifat Fisika-Kimia, Potensi Target dan Toksikologi Senyawa Isolat Murni dari Bahan Alam dengan Metode In Silico}

\section{Abstrak}

Beberapa penelitian sebelumnya menunjukkan isolat murni dari Sumatera Barat memiliki potensi yang sangat besar untuk dikembangkan menjadi Active Pharmaceutical Ingredients (APIs). PT Andalas Sitawa Fitolab telah memproduksi 10 isolat murni yang sangat potensial dikembangkan menjadi kandidat obat baru. Isolat murni yang diperoleh dari PT Andalas Sitawa Fitolab dianalisis secara in silico untuk memprediksi sifat fisikokimia, toksisitas dan potensi target. Uji in silico yang dilakukan menggunakan big data dan Machine Learning untuk memprediksi sifat fisika-kimia, potensi target dan sifat toksik. Tujuan dalam penelitian ini adalah penapisan awal untuk melihat potensi dari senyawa yang diperoleh. Sepuluh senyawa di gambar secara dua dimensi, dianalisis menggunakan perangkat lunak dan server. Perangkat lunak yang digunakan adalah Marvin sketch, QSAR Toolbox, Swiss potention target dan ChemBioDraw dan dianalisis sifat kimia dari senyawa tersebut. Hasil yang diperoleh adalah Log P berada pada rentang -0,54 sampai 4,64 dan Polar Surface Area (PSA) pada rentang 20,23 sampai 315,21 . Senyawa asiaticoside tidak memenuhi aturan Lipinski. Senyawa dengan potensi hazard tinggi adalah catechin, curcumin, andrographolide, asiaticoside, deoxyelephantopin, ethylmethoxycinnamate, alpha mangostin dan piperine. Senyawa curcumin, alpha mangostin, plumbagin dan piperine memiliki target protein spesifik. Dari hasil penelitan ini diperoleh prediksi senyawa asiaticoside memiliki potensi hazard tinggi jika dikembangkan menjadi senyawa obat.

Kata Kunci: analisis sifat fisika-kimia, in silico, isolat murni, toksikologi 


\section{Pendahuluan}

PT Andalas Sitawa Fitolab didirikan pada tahun 2017 dan menjadi mitra bagi laboratorium Biota Sumatra, Universitas Andalas dalam upaya hilirisasi dan pemanfaatan hasil riset. Perusahaan ini memproduksi senyawa baku pembanding (reference substances) atau isolat murni tumbuhan obat Indonesia dan bahan baku obat tradisional terstandardisasi. Bahanbahan yang dianalisis dalam penelitian ini adalah berasal dari database senyawasenyawa baku pembanding yang diproduksi oleh PT Andalas Sitawa Fitolab terdiri dari 10 senyawa. ${ }^{1}$ Bahan baku yang terstandarisasi diperoleh dari tumbuhan khas Sumatra Barat. Senyawa bahan baku pembanding ini telah diisolasi dan telah melalui proses pemurnian.

Pengembangan obat adalah proses dinamis yang berkembang dengan cepat dan dipermudah dengan komputer (Machine Learning). Pemodelan interaksi antara zat kimia dan target biologi memudahkan untuk pengembangan pharmacophores baru. Hasil pemodelan ini berupa Structure-activity relationships (SARs) untuk memprediksi efek dan proses dalam tubuh berdasarkan struktur kimia. ${ }^{2}$ Metode analisis toksikologi secara in silico memberikan data yang penting untuk pengambilan keputusan dan panduan dalam desain obat, metode ini mampu meringkas waktu, menerapkan prinsip etika dengan penurunan jumlah hewan percobaan dan menghemat dana. ${ }^{3}$ Penggunaan komputasi dalam bidang penelitian kimia adalah tren baru dalam pengembangan obat baru seperti menggunakan Artificial Intelligence (AI), database dan big data, dengan demikian dapat membantu memahami sifat sifat suatu senyawa jauh lebih cepat dan efektif dalam menapis calon obat baru.

Penelitian efek senyawa bahan alam masih dominan berbentuk multiple compound terhadap suatu penyakit. Senyawa bahan alam yang dianalisis efeknya berbentuk single compound dilakukan karena lebih spesifik terhadap target aksi. Dengan teknologi komputasi, molekul dapat didesain, diprediksi sifat fisika kimia dan prediksi metode dalam melakukan sintesis lebih efisien.
Tujuan penelitian iniadalah memberikan gambaran awal tentang sifat fisika-kimia, efek toksikologi dan potensi target menggunakan metode komputasi (Machine Learning). Hasil penelitian ini diharapkan menjadi data pembanding uji in vivo dan in vitro sehingga mampu memgurangi penggunaan hewan percobaan. Isolat murni yang telah diisolasi dari PT Andalas Sitawa Fitolab sebelumnya belum dilakukan uji SARs, dengan dilakukan uji tersebut diharapkan diperoleh gambaran awal kandidat obat yang akan diteliti, seperti data sifat fisika kimia, toksisitas dan potensi target. Setelah dikumpulkan data-data tersebut diharapkan dikembangkan obat baru yang berbasis bahan alam yang sangat kaya di Indonesia. Kandidat obat ini dapat didesain modofikasi rantai sampingnya dengan parameter-parameter yang digunakan. Datadata potensi target berupa enzim, protein dan makromolekul dapat dijadikan panduan dan prediksi dalam mengetahui efek dan target senyawa tersebut. Diharapkan dengan menggunakan metode komputasi efek dan target spesifik senyawa tersebut dapat digali lebih dalam sebelum dilakukan sintesis dan uji in vivo dan in vitro.

\section{Metode}

2.1. Bahan

Bahan yang digunakan adalah bahan isolat murni yang telah diketahui struktur molekulnya dari PT Andalas Sitawa selanjutnya digambar software di Marvin Sketch.

\subsection{Perangkat lunak dan keras}

Alat-alat yang digunakan pada penelitian ini adalah Komputer dengan $C P U$ Intel ${ }^{\circledR}$ Core (TM) i7-8565U CPU @2,2.50 GHz, Windows 10 64-Bit Operation System. Perangkat lunak yang digunakan adalah Marvin Sketch versi 16.9.12, ChemBio versi 19.0.0.22, OECD QSAR Toolbox versi 4.3 dan Swiss Target Prediction.

\subsection{Cara Kerja}

Struktur kimia senyawa uji di gambar menggunakan software Marvin Sketch, selanjutnya senyawa tersebut dianalisis 
kecocokan dan kesusaian strukturnya, file senyawa tersebut disimpan dalam bentuk format. Sdf. Nama senyawa selanjutnya di input dalam pubchem https://pubchem. ncbi.nlm.nih.gov ${ }^{4}$ diperiksa kembali nama International Union of Pure and Applied Chemistry (IUPAC), dan kode Chemical Abstract Service (CAS), masing-masing nomor Chemical Abstract Service (CAS) disimpan. Format penyimpanannya yaitu data (.sdf) yang disimpan tersebut selanjutnya dianalisis menggunakan ChemBio. Dipilih bagian analysis for chemical properties untuk diperoleh hasil prediksi sifat kimia fisika dari masing-masing senyawa. Hasil Prediksi yang diperoleh menggunakan ChemBio adalah Boiling Point (K), Melting Point (K), Critical Temperature (K), Critical Press (Bar), Gibbs Energy (kJ/mol), Log P, MR (Molar Refractivity), TPSA (Topological Polar Surface Area), dan konstanta disosiasi asam (pKa). Analisis sifat toksisitas suatu senyawa dilakukukan menggunakan software QSAR Toolbox, QSAR Toolbox adalah program komputer yang dikembangkan oleh The Organisation for Economic Co-operation and Development (OECD) dan ECHA (European Chemical Agency). Program ini terdiri dari big data yang diperoleh dari data eksperimental, hasil penelitian karakter struktur senyawa (structural alerts) yang menunjukkan sifat toksik, dan perangkat lunak ini mampu memprediksi parameter dua dimensi suatu senyawa, dapat digunakan juga untuk mengestimasi sifat suatu senyawa dengan pendekatan read-across, analisis kecenderungan (trend analysis) dan Quantitative structure-activity relationship (QSAR). Selanjutnya, Chemical Abstract Service (CAS) diinput kedalam perangkat lunak, selanjutnya dipilih profiling data meliputi data toksisitas mutagen, karsinogen, lipinski rule of five, dan Toxic Hazard.

\section{Hasil}

Hasil prediksi sifat fisika kimia senyawa seperti Boiling Point (K), Melting Point (K), Critical Temperature (K), Critical Press (Bar), Gibbs Energy (Kj/mol), Log P, Molecular Weight (g/mol), Molar Refractivity, Polar
Surface Area (PSA) disajikan pada Tabel 1. Prediksi toksisitas (Tabel 2) diperoleh structurealertsepertiAlkil-benzen(Gambar1), Quinon (Gambar 2), alpha, beta-unsaturated carbonyls (Gambar 3) dan 1,3-Benzodioxoles (Gambar 4) yang dapat menyebabkan potensi karsinogen dan mutagen. Potensi target (Tabel 3) yang diperoleh yaitu Monoamine oxidase A, Beta amyloid A4 protein, Histone acetyltransferase p300, Prostaglandin E synthase, Toll-like receptor (TLR7) TLR9), Isocitrate dehydrogenase [NADP] cytoplasmic, Arachidonate 15-lipoxygenase, Arachidonate 12-lipoxygenase, Fatty acid synthase, Histone acetyltransferase p300 dan Monoamine oxidase B.

\section{Pembahasan}

4.1. Sifat Fisika Kimia

Prediksi sifat fisika kimia dari senyawa yang diuji dapat dilihat di Tabel 1. Boiling point (titik didih) adalah suhu dimana tekanan uap cairan sama dengan tekanan keseluruhan yang dialami oleh cairan. ${ }^{5}$ Cairan dikatakan telah mendidih jika dihasilkan uap. Titik didih hasil prediksi yang rendah adalah hydroxychavicol dengan suhu 509,5 Kelvin $\left(236,5^{\circ} \mathrm{C}\right)$ dan yang paling tinggi adalah andrographolide 1201,5 Kelvin $\left(928,5^{\circ} \mathrm{C}\right)$. Melting point (titik lebur) adalah suhu di mana zat padatan berubah wujud menjadi zat cair. ${ }^{6}$ Senyawa dengan titik leleh terendah adalah ethyl-P-Methoxycinnamate 322,92 K dan yang tertinggi adalah alpha mangostin 914,98 K. Data titik lebur digunakan untuk mengkarakterisasi senyawa organik dan mengkonfirmasi kemurniannya, titik lebur senyawa murni selalu lebih tinggi dari titik lebur senyawa yang belum murni. Titik lebur meningkat dengan meningkatnya berat molekul. Kenaikan titik didih diikuti dengan meningkatnya ukuran molekul. ${ }^{7}$ Titik kritis (Critical Temperature) temperatur adalah suhu suatu senyawa tidak dapat berubah menjadi cair meskipun telah diberikan tekanan. ${ }^{6}$ Titik kritis terendah adalah senyawa hydroxychavicol 725,15 dan tertinggi adalah senyawa 1045,19 alpha mangostin. Titik kritis tekanan (Critical Press) adalah tekanan minimum yang harus diterapkan 
Tabel 1. Analisis sifat kimia dā fisika

\begin{tabular}{|c|c|c|c|c|c|c|c|c|c|c|}
\hline & 芯 & 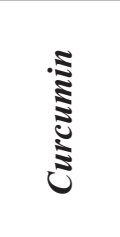 & 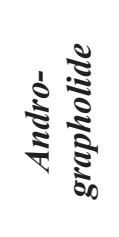 & 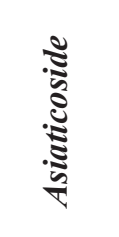 & 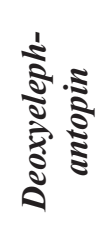 & 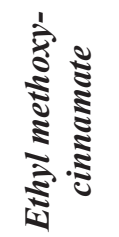 & 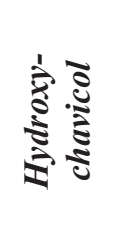 & 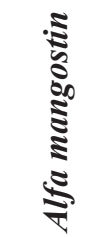 & 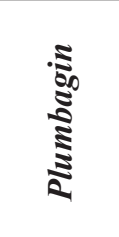 & $\frac{\sqrt{2}}{3}$ \\
\hline $\begin{array}{c}\text { Boiling } \\
\text { Point }(\mathrm{K})\end{array}$ & 1049,1 & 1065,5 & 1021,5 & 1449,7 & 837,0 & 590,62 & 509,5 & 1201,2 & 719,02 & 785,09 \\
\hline $\begin{array}{c}\text { Melting } \\
\text { Point (K) }\end{array}$ & 868,12 & 761,4 & 638,31 & 623,0 & 497,4 & 322,92 & 327,1 & 914,98 & 532,27 & 495,01 \\
\hline $\begin{array}{c}\text { Critical } \\
\text { Temperature } \\
\text { (K) }\end{array}$ & 964,3 & 982,7 & 964,95 & - & 958,8 & 765,22 & 725,2 & 1045,2 & 858,1 & 905,85 \\
\hline $\begin{array}{c}\text { Critical } \\
\text { Press (Bar) }\end{array}$ & 68,3 & 22,5 & 18,45 & - & 969,5 & 24,65 & 41,09 & 20,16 & 42,72 & 24,36 \\
\hline $\begin{array}{c}\text { Gibbs } \\
\text { Energy } \\
(\mathrm{Kj} / \mathrm{mol})\end{array}$ & $-509,87$ & $-285,14$ & $-405,03$ & - & $-498,6$ & $-182,21$ & 70,53 & $-225,8$ & $-178,59$ & 268,19 \\
\hline Log P & 1,5 & 2,56 & 1,97 & $-0,54$ & 1,72 & 2,41 & 2,7 & 4,64 & 0,87 & 2,78 \\
\hline $\begin{array}{c}\text { Molecular } \\
\text { Weight } \\
(\mathrm{g} / \mathrm{mol})\end{array}$ & 290,27 & 368,38 & 350,45 & 959,13 & 344,36 & 206,24 & 134,18 & 410,47 & 188,18 & 285,34 \\
\hline $\begin{array}{c}\text { Molar } \\
\text { Refractivity } \\
(\mathrm{cm} 3 / \mathrm{mol})\end{array}$ & 74,05 & 105,79 & 94,66 & 231 & 90,51 & 60,34 & 42,24 & 120,99 & 53,97 & 85,91 \\
\hline $\begin{array}{c}\text { Polar } \\
\text { Surface } \\
\text { Area (PSA) }\end{array}$ & 110,38 & 93,06 & 86,99 & 315,21 & 78,9 & 35,53 & 20,23 & 96,22 & 54,37 & 38,77 \\
\hline $\mathrm{pKa}$ & 16,17 & 8,863 & 16,4 & 18,796 & 13,56 & - & 9,772 & 7,544 & 6,793 & $-0,13$ \\
\hline
\end{tabular}

Keterangan $=-($ Hasil Prediksi tidak ditemukan $)$

untuk membawa pencairan pada suhu kritis. ${ }^{6}$ Senyawa titik kritis tekanan terendah adalah andrographolide 18,45 bar dan tertinggi adalah senyawa deoxyelephantopin 969,5 Bar.

Energi bebas Gibbs dilambangkan dengan $\Delta \mathrm{G}$ digunakan untuk memprediksi apakah suatu reaksi dapat berjalan secara spontan atau tidak. Nilai $\Delta \mathrm{G}<0$ berarti reaksi dapat berlangsung dengan spontan, $\Delta \mathrm{G}=0$ reaksi berlangsung dalam kesetimbangan, $\Delta \mathrm{G}$ $>0$ reaksi berjalan tidak spontan. ${ }^{6}$ Senyawa Hydroxychavicol dan piperine memiliki nilai $\Delta \mathrm{G}>0$, dimana reaksi tidak berjalan spontan. Senyawa catechin, curcumin, andrographolide, asiaticoside, deoxyelephantopin, ethyl-p-methoxycinnamate, alpha mangostin dan plumbagin memiliki $\Delta \mathrm{G}<0$ dimana reaksi dapat berjalan dengan spontan.

Aturan Lipinski mensyaratkan calon obat yang baik adalah memiliki massa molekul lebih kecil dari $500 \mathrm{~g} / \mathrm{mol}$, $\log$ P lebih kecil dari 5, memiliki donor hidrogen sebanyak 5, dan memiliki ikatan hidrogen sebagai akseptor sebanyak sepuluh. ${ }^{8}$ Senyawa asiaticoside tidak memenuhi kriteria Lipinski, dalam hal ini asiaticoside digolongkan sebagai calon obat yang tidak memenuhi syarat dari Lipinski dan tidak ada nilai prediksi Critical Temperature (K), Critical Press (Bar) dan Gibbs Energy (Kj/mol). Refraksi molar (Molar Refractivity) adalah ukuran polarisasi total suatu zat dalam $\mathrm{cm}^{3} / \mathrm{mol}$ yang tergantung pada suhu, indeks bias, dan tekanan. ${ }^{9}$

Rentang Molar Refractivity yaitu 42,24 sampai dengan $231 \mathrm{~cm}^{3} / \mathrm{mol}$. Topology Polar surface area (TPSA) dalam kimia medisinal digunakan untuk menganalisis kemampuan obat untuk masuk kedalam sel. Nilai TPSA untuk obat yang memiliki bioavaibilitas yang baik yaitu berada pada rentang 20$130 \AA^{2}{ }^{10}$ Senyawa asiaticoside memiliki 
Tabel 2. Analisis toksisitas dan aturan Lipinski

\begin{tabular}{|c|c|c|c|c|c|c|c|c|c|c|}
\hline & ט & 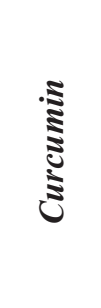 & 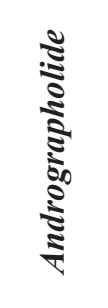 & 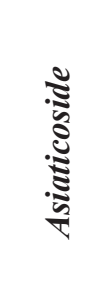 & 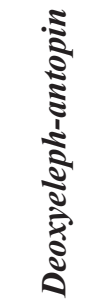 & 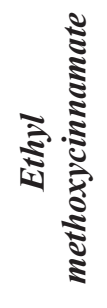 & 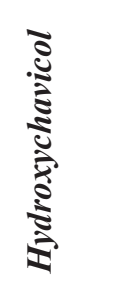 & 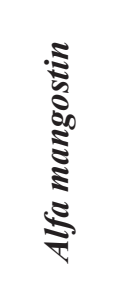 & 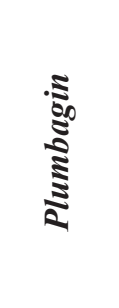 & 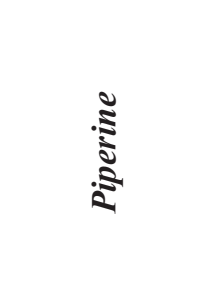 \\
\hline Mutagen & Tidak & Tidak & Tidak & Tidak & Tidak & Tidak & $\begin{array}{l}\text { Alkil- } \\
\text { benzen }\end{array}$ & $\begin{array}{l}\text { Alkil- } \\
\text { benzen }\end{array}$ & Quinon & $\begin{array}{c}\text { alpha, beta- } \\
\text { unsaturated } \\
\text { carbonyls }\end{array}$ \\
\hline Karsinogen & Tidak & Tidak & Tidak & Tidak & Tidak & Tidak & $\begin{array}{l}\text { Alkil- } \\
\text { benzen }\end{array}$ & $\begin{array}{l}\text { Alkil- } \\
\text { benzen }\end{array}$ & Quinon & $\begin{array}{c}1,3- \\
\text { Benzodioxoles }\end{array}$ \\
\hline $\begin{array}{l}\text { Kriteria } \\
\text { Lipinski } \\
\quad \text { rule }\end{array}$ & Iya & Iya & Iya & Tidak & Iya & Iya & Iya & Iya & Iya & Iya \\
\hline $\begin{array}{c}\text { Potensi } \\
\text { Toxic } \\
\text { Hazard }\end{array}$ & Tinggi & Tinggi & Tinggi & Tinggi & Tinggi & Tinggi & Rendah & Tinggi & Sedang & Tinggi \\
\hline
\end{tabular}

nilai PSA 315,21. Nilai ini mengindikasikan senyawa ini sulit berpenetrasi ke dalam sel. Gugus polar menyebabkan desolvasi yang menyebabkan perpindahan dalam lingkungan air pada ekstraseluler ke membrane lipofilik, PSA dipengaruhi oleh konformasi molekul, metode ini memperhitungkan nilai dari energi minimum dari konformasi molekul. ${ }^{11}$

Konstanta disosiasi asam (pKa) adalah minus logaritma basis 10 , semakin kecil nilai pKanya maka semakin asam. ${ }^{12}$ Pada senyawa ethyl-p-methoxycinnamate nilai prediksi $\mathrm{pKa}$ tidak ada karena tidak adanya atom yang mengalami ionisasi.

Prediksi sifat mutagen dan karsinogen dalam penelitian ini menggunakan metode structure alert yaitu mendeteksi struktur kimia yang mengindikasikan atau berkaitan dengan toksisitas. Structure alerts adalah struktur kimia yang mengindikasikan sifat toksik suatu senyawa yang menunjukan bagian dari struktur yang mempunyai potensi mutagen, karsinogen, antimutagen dan antikarsinogen. Structure alerts terdiri dari struktur molekul, jenis ikatan atau gugus fungsi. Terdapat dua jenis model structure alert yaitu aturan berbasis manusia (human-based rules) dan aturan berbasis induksi (induction based rules). ${ }^{13,14}$ Structure alert pada senyawa hydroxychavicol dan alpha mangostin yaitu alkil benzene (Gambar 1). Gugus ini juga mampu menjadi agen alkilasi dan inhibitor
DNA topoisomerase II yang memiliki sifat toksik pada gugus benzen. ${ }^{15}$

Senyawa Plumbagin memiliki structure alert Quinon (Gambar 2). Quinon adalah gugus yang kaya elektrofil dan memiliki sifat antioksidan. Senyawa ini mudah tereduksi. Mekanisme toksik dari Quinon yaitu alkilasi dari nukleofil dan menstimulasi oxidative stress. Sebagai Michael acceptors yang merupakan penambahan nukleofilik dari karbanion. Quinon dapat menyebabkan oksidasi pada DNA dan membentuk adisi yang bersifat mutagenik dengan adenin dan guanin. ${ }^{16}$ Metabolit Quinon seperti benzene, hidroquinon dan p-benzoquinon, dapat menyebabkan DNA adducts (Ikatan DNA yang menyebabkan kanker). ${ }^{17,18}$

Senyawa Quinon memiliki sifat redox, dapat berubah karena proses enzim dan non enzim. Quinon dapat membentuk reactive oxygen species (ROS), superoksida, hydrogen peroksida dan radikal hidroksil. Terbentuknya reaksi reactive oxygen species (ROS) oleh Quinon menyebabkan penurunan viabilitas, pelepasan Lactate dehydrogenase (LDH), kerusakan DNA, dan produksi ROS dalam sel A549. ${ }^{19}$

Piperine memiliki structure alert alpha, beta-unsaturated carbonyls mampu menyebabkan mutagen (Gambar 3). Structure alert $\alpha, \beta$-unsaturated carbonyls adalah molekul reaktif bis-electrophiles 


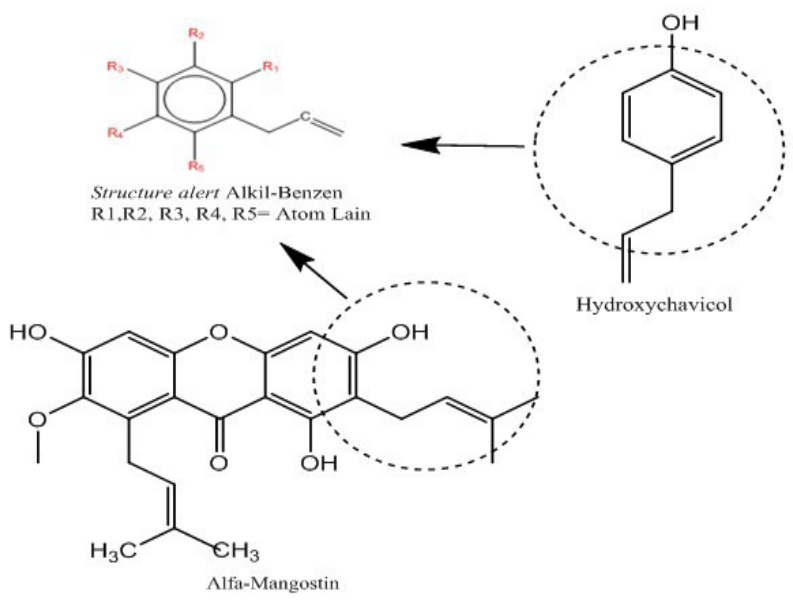

Gambar 1. Structure alert dari Alpha Mangostin dan Hydroxychavicol

yang berinteraksi dengan elektron pada makromolekul. Karena adanya konjugasi dengan grup karbonil, $\beta$-carbon terpolarisasi dan menjadi sisi masuknya nukleofilik, termasuk dalam kategori classic Michael type addition. ${ }^{20}$ Mekanisme genotoksik seperti pembentukan cyclic adducts, interaksi frameshift, strand breaks, dan ikatan silang. Structure alert alpha, beta-unsaturated carbonyls dapat menyebabkan epoksidasi metabolik dan pembentukan radikal. ${ }^{21}$

Piperine memiliki structure alert yang mempunyai potensi antikarsinogen yaitu 1,3-Benzodioxoles (Gambar 4). Gugus structure alert 1,3-Benzodioxoles sebelumnya telah diteliti potensi Benzodioxole digunakan sebagai antitumor, antibakteri, antijamur, antiparasit, antimalaria, antioksidan, pestisida dan herbisida. ${ }^{22}$ Temuan ini menunjukkan adanya 1,3-Benzodioxoles menghambat proliferasi sel kanker usus besar pada manusia. ${ }^{23}$ Pada senyawa apiol yang memiliki structure alert 1,3-Benzodioxoles mampu menghambat proliferasi sel kanker melalui induksi siklus sel fase G0 / G1 dan apoptosis, mengaktivasi pensinyalan p53 dalam sel kanker usus besar COLO 205. Apiole dapat digunakan sebagai pengobatan potensial dalam kanker. ${ }^{24}$ Senyawa 4,7-Dimethoxy-5methyl-1,3-benzodioxole mampu menekan inducible nitric oxide synthase (iNOS) dan siklooksigenase-2 (COX-2). ${ }^{25}$

\subsection{Potensi Toxic Hazard}

Potensi hazard merupakan parameter yang memprediksi kemungkinan sifat toksik dari kandidat obat. Cramer membagi potensi hazard menjadi decision tree yang terdiri dari hazard tinggi, sedang dan rendah. ${ }^{26}$ Potensi Hazard yang tinggi adalah senyawa catechin, curcumin, andrographolide, asiaticoside deoxyelephantopin, ethylmethoxycinnamate, alpha mangostin dan piperine. Catechin memiliki hazard pada struktur heterocyclic.<smiles>O=C1C=CC=CC1=O</smiles><smiles>O=C1C=CC(=O)C=C1</smiles>

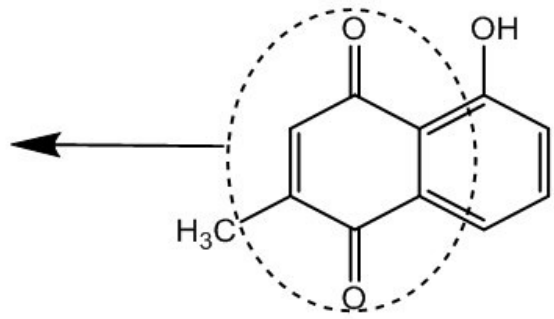

Structure alert Quinon

Gambar 2. Structure alert Quinon 


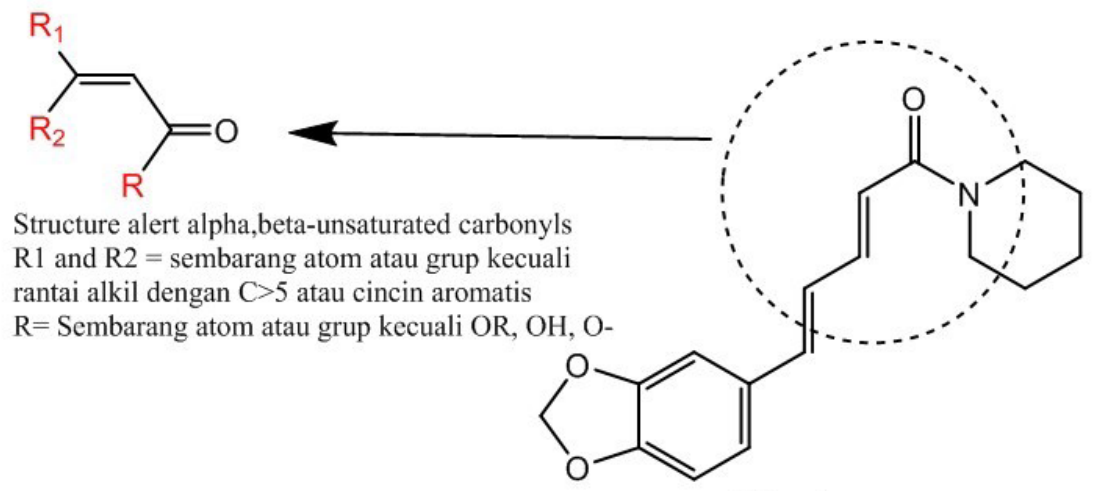

Piperine

Gambar 3. Structure Alert alpha, beta-unsaturated carbonyls

Curcumin memiliki hazard yaitu struktur aromatic rings with substituents dan lebih dari satu cincin aromatis. Andrographolide memiliki potensi hazard yaitu adanya struktur Heterocyclic, Lactone atau cyclic diester. Asiaticoside memiliki struktur Heterocyclic. Deoxyelephantopin memiliki potensi hazard karena adanya struktur Heterocyclic, Lactone atau cyclic diester, Lactone, fused to another ring, atau 5-or6-membered $\alpha, \beta$-unsaturated lactone. Alpha-mangostin memiliki hazard tinggi karena memiliki struktur Heterocyclic. Piperine memiliki hazard pada bagian struktur Heterocyclic dan heterocyclic ring with complex substituents. Ethyl methoxycinnamate memiliki hazard pada struktur aromatik dan substituen cincin. Plumbagin memiliki hazard dengan katagori sedang karena memiliki struktur aromatik dan subsituen cincin. Hydroxychavicol memiliki hazard rendah karena adanya struktur aromatik dengan substituen cincin.

\subsection{Potensi Target}

Potensi target dan protein yang menjadi target spesifik dari senyawa yang diuji dapat dilihat pada Tabel 3. Senyawa curcumin, Alpha mangostin, Plumbagin dan Piperine memiliki target protein spesifik yang diprediksi menggunakan Swiss prediction target. Spesies yang memiliki target adalah protein target pada manusia. Kelas potensi target terdiri dari protein, enzim dan makromolekuler. Database yang digunakan adalah 224.412 molekul yang terdiri dari 1700 protein manusia. ${ }^{27}$ Kelas potensi target adalah prediksi target berdasarkan database dikelompokkan berdasarkan makromolekul. Target spesifik adalah kecocokan (probability) $100 \%$ kemiripan dari target spesifik dari database. Swiss prediction target memprediksi target spesifik menggunakan data penelitian sebelumnya yang terdiri dari aktifitas spesifik seperti $\mathrm{IC}_{50}$ atau $\mathrm{EC}_{50}$, target spesifik diperoleh dari ligand similarity dan identifikasi scaffold. Pada senyawa andrographolide dan catechin tidak ditemukan spesies dan target spesifik.

Masing-masing target spesifik yang diperoleh adalah Monoamine oxidase A, Beta amyloid A4 protein, Histone acetyltransferase

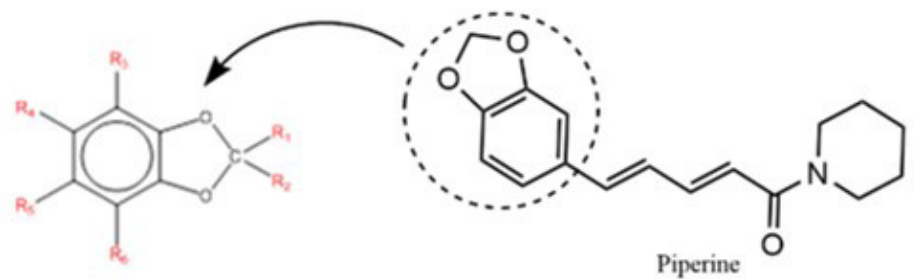

Structure alert 1,3-Benzodioxoles

R1,R2= Sembarang atom atau grup kecuali R1-R2= Karbon alifatik

R3, R4, R5, R6 = Atom atau grup

Gambar 4. Structure alert 1,3-Benzodioxoles 
Tabel 3. Potensi Target dan Target spesifik

\begin{tabular}{|c|c|c|c|c|}
\hline No & Nama Senyawa & Spesies & Kelas Potensi Target & Target spesifik \\
\hline 1 & Catechin & - & - & - \\
\hline 2 & Curcumin & $\begin{array}{l}\text { Homo } \\
\text { Sapiens }\end{array}$ & $\begin{array}{l}\text { Lyase (24\%), Primary active transporter } 4 \% \text {, } \\
\text { Oxidoreductase } 12 \% \text {, Membran receptor } 4 \% \text {, } \\
\text { Unclassified protein 4\%, Enzyme 16\%, Toll-like } \\
\text { and il-1 Receptors, Protease 4\%, Isomerase } \\
4 \% \text {, Transcription factor } 4 \% \text {, kinase } 16 \%\end{array}$ & $\begin{array}{l}\text { Monoamine } \\
\text { oxidase A, } \\
\text { Beta amyloid A4 } \\
\text { protein, Histone } \\
\text { acetyltransferase } \\
\text { p300, } \\
\text { Prostaglandin E } \\
\text { synthase, } \\
\text { Toll-like receptor } \\
\text { (TLR7/TLR9) }\end{array}$ \\
\hline 3 & Andrographolide & - & - & - \\
\hline 4 & Asiaticoside & $\begin{array}{l}\text { Homo } \\
\text { Sapiens }\end{array}$ & $\begin{array}{l}\text { Enzyme } 16 \% \text {, Transcription factor } 12 \% \text {, } \\
\text { Phosphatase 16\%, Protease 4\%, Ligand-gated } \\
\text { ion channel } 8 \% \text {, Family A G Protein-coupled } \\
\text { receptor } 12 \% \text {, Nuclear Receptor 4\%, kinase } \\
16 \% \text {, Secreted Protein 4\%, Oxidoreductase 4\%, } \\
\text { Other ion channel 4\% }\end{array}$ & - \\
\hline 5 & Deoxyelephantopin & $\begin{array}{l}\text { Homo } \\
\text { Sapiens }\end{array}$ & $\begin{array}{l}\text { Enzyme 36\%, Kinase 8\%, Primary active } \\
\text { transporter 4\%, Transferase 4\%, Phosfatase } \\
\text { 4\%, Cytochrome P450 4\%, Nuclear Receptor } \\
\text { 4\%, Lyase 4\%, Voltage-gated ion channel 4\%, } \\
\text { Family A G Protein-coupled receptor 4\%, } \\
\text { Oxidoreductase } 8 \% \text {, Phosphodiesterase } 8 \% \text {, } \\
\text { Protease 4\%, Hydrolase 4\% }\end{array}$ & - \\
\hline 6 & $\begin{array}{l}\text { Ethyl } \\
\text { methoxycinnamate }\end{array}$ & $\begin{array}{l}\text { Homo } \\
\text { Sapiens }\end{array}$ & $\begin{array}{l}\text { Lyase 48\%, Cytochrome P450 8\%, Familly C G } \\
\text { Protein-Coupled receptor 4\%, Nuclear Receptor } \\
\text { 4\%, Protease 4\%, Toll-like and Il-1 receptors 4\%, } \\
\text { Kinase } 12 \% \text {, Enzyme } 8 \% \text {, Oxidoreductase } 8 \%\end{array}$ & - \\
\hline 7 & Hydroxychavicol & $\begin{array}{l}\text { Homo } \\
\text { Sapiens }\end{array}$ & $\begin{array}{l}\text { Family A G Protein-coupled receptor 16\%, } \\
\text { Lyase } 8 \% \text {, Nuclear Receptor 4\%, Oxidoreductase } \\
4 \% \text {, Voltage-gated ion channel } 8 \% \text {, Transferase } \\
4 \% \text {, Structural Protein, Hydrolase 4\%, Ligan- } \\
\text { gated ion channel 12\%, Eraser 16\%, } \\
\text { Cytochrome P45O, Enzyme } 16 \%\end{array}$ & - \\
\hline 8 & Alpha mangostin & $\begin{array}{l}\text { Homo } \\
\text { Sapiens }\end{array}$ & $\begin{array}{l}\text { Enzyme 16\%, Phosphodiesterase 4\%, Protease } \\
\text { 4\%, Phosphatase 4\%, Secreted Protein 4\%, } \\
\text { Family B G Protein-Coupled Receptor 4\%, } \\
\text { Unsclassified Protein 4\%, Other Membrane } \\
\text { Protein 4\%, Kinase 20\%, Hydrolase 4\%, } \\
\text { Transcription Factor 4\%, Oxidoreductase } \\
12 \% \text {, Other Cytosolic Protein 8\%, Cytochrome } \\
\text { P450 4\%, Transferase 4\% }\end{array}$ & $\begin{array}{l}\text { Isocitrate } \\
\text { dehydrogenase } \\
\text { [NADP] } \\
\text { cytoplasmic, } \\
\text { Arachidonate 15- } \\
\text { lipoxygenase, } \\
\text { Arachidonate 12- } \\
\text { lipoxygenase, Fatty } \\
\text { acid synthase }\end{array}$ \\
\hline 9 & Plumbagin & $\begin{array}{l}\text { Homo } \\
\text { Sapiens }\end{array}$ & $\begin{array}{l}\text { Enzyme 24\%, } 4 \% \text { Writer, Other Ion Channel } 4 \% \text {, } \\
\text { Volatage-gated ion channel } 4 \% \text {, Adhesion } 4 \% \text {, } \\
\text { Lyase } 12 \% \text {, Unclassified Protein 12\%, Protease } \\
12 \% \text {, Oxidoreductase 12\%, Kinase } 8 \% \text {, } \\
\text { Phosphatase } 4 \%\end{array}$ & $\begin{array}{l}\text { Histone } \\
\text { acetyltransferase } \\
\text { p300 }\end{array}$ \\
\hline 10 & Piperine & $\begin{array}{l}\text { Homo } \\
\text { Sapiens }\end{array}$ & $\begin{array}{l}\text { Enzyme } 32 \% \text {, Ligase 4\%, Membrane Receptor 4\%, } \\
\text { Oxidoreductase 4\%, Phosphodiesterase 4\%, } \\
\text { Volatage-gated ion channel 12\%, Kinase 20\%, } \\
\text { Protease } 12 \%\end{array}$ & $\begin{array}{l}\text { Monoamine } \\
\text { oxidase B }\end{array}$ \\
\hline
\end{tabular}

Keterangan $=-($ Hasil Prediksi tidak ditemukan $)$ 
p300, Prostaglandin E synthase, Toll-like receptor (TLR7/TLR9), Arachidonate 12lipoxygenase, Isocitrate dehydrogenase [NADP] cytoplasmic, Arachidonate 15lipoxygenase, dan Fatty acid synthase. Monoamine oxidase $A$ adalah produk dari dua gen yang terhubung dengan $X$-Linked Gen, dan berperan dalam metabolisme amina biogenik di sistem saraf pusat dan tepi. ${ }^{28}$ Monoamine oxidase A dan B berperan terhadap penyakit yang disebabkan oleh neurotransmitter seperti ganguan mental, ganguan motorik dan saraf..$^{29}$ Beta amyloid A4 protein adalah protein yang berperan dalam penyakit alzeimer. ${ }^{30}$ Histone acetyltransferase p300 memiliki kemampuan mengaktivasi ekspresigen, mengatur transkripsi DNA repressor protein yang menyebabkan penyakit leukemia. ${ }^{31}$ Mikrosomal prostaglandin $E$ synthase, mampu menkonversi Prostaglandin H2 (PGH2) menjadi PGE2 (Prostaglandin E2), sehingga membuat peningkatan jumlah acrolein dalam fibroblast di paru-paru. ${ }^{32}$

Toll-like receptor (TLR) berperan dalam sistem kekebalan tubuh dengan mengenali pola-pola molekuler terkait-patogen yang berasal dari berbagai mikroba. Sinyal TLR mengaktivasi faktor transkripsi Nuclear Factor Kappa-light-chain-enhancer of activated $B$ cells (NF-Kb) dan Interferon regulatory factors (IRF), yang merangsang respon. ${ }^{33}$ Arachidonate 12- lipoxygenase berperan dalam sistem penyebab aterosklerosis dan gangguan transmisi saraf. ${ }^{34}$ Mutasi Isocitrate dehydrogenase (NADP) cytoplasmic memiliki hubungan dengan pembentukan glioma dan non-central nervous system (CNS) malignancies..$^{35}$ Arachidonate 15- lipoxygenase berperan dalam penyakit liver ${ }^{36}$, pembengkakan pada jaringan adiposa, kanker kolekteral ${ }^{37}$, dan asma. ${ }^{38}$ Fatty acid synthase berperan dalam penyebab obesitas dan kanker. ${ }^{39}$

\section{Simpulan}

Dari Hasil percobaan diatas, hanya senyawa asiaticoside yang tidak memenuhi aturan obat yang baik dari Lipinski. Senyawa hydroxycarviol, alpha mangostin, plumbagin dan Piperine memiliki potensi karsinogen dan mutagen. Senyawa curcumin, alpha mangostin, plumbagin dan piperine memiliki target protein spesifik, dengan target spesifik yang diperoleh dapat digunakan sebagai awal penapisan virtual yang dapat dilanjutkan penambatan (docking) dan simulasi dinamika molekular.

\section{Daftar Pustaka}

1. Fitolab PAS. FitoPure Naturally Refference Substance. [cited 2019 Sep 14]. Available from: https://andalasfitolab. com/home/about/

2. Kruhlak NL, Benz RD, Zhou H, Colatsky TJ. (Q)SAR modeling and safety assessment in regulatory review. Clin Pharmacol Ther. 2012;91(3):529-34.

3. Idakwo G, Luttrell J, Chen M, Hong $\mathrm{H}$, Zhou Z, Gong P, et al. A review on machine learning methods for in silico toxicity prediction. J Environ Sci Heal Part C Environ Carcinog Ecotoxicol Rev. 2018;36(4):169-91.

4. NCBI, Medicine, U.S. National Library of Information NC for B. Explore Chemistry Quickly find chemical information from authoritative sources. US National Library of Medicine National Institutes of Health Search databaseSearch term Search. 2019 [cited 2019 Sep 10]. Available from: https://pubchem.ncbi.nlm.nih.gov/

5. Goldberg D. 3,000 Solved Problems In Chemistry. First Edit. McGraw-Hill; 2011. $624 \mathrm{p}$.

6. Chang R. Chemistry. 11th Edition. McGraw-Hill; 2012.

7. Sarker SD, Nahar L. Chemistry for Pharmacy Students: General, Organic, and Natural Product Chemistry. Coleraine: John Wiley \& Sons Ltd; 2013. 1-383 p.

8. Lipinski CA. Lead- and druglike compounds: The rule-of-five revolution. Drug Discov Today Technol. 2004;1(4):337-41.

9. Born M, Wolf E. Electromagnetic Theory of Propagation Interference and Diffraction of Light. 7th ed. Cambridge University Press; 1999.

10. Daina A, Michielin O, Zoete V. SwissADME: A free web tool to evaluate 
pharmacokinetics, drug-likeness and medicinal chemistry friendliness of small molecules. Sci Rep. 2017;7(March):1-13.

11. Palm K, Luthman K, Ungell AL, Strandlund G, Beigi F, Lundahl P, et al. Evaluation of dynamic polar molecular surface area as predictor ofdrug absorption: Comparison with other computational and experimental predictors. J Med Chem. 1998;41(27):5382-92.

12. Petrucci RH, Herring FG, Madura JD, Bissonnette C. General chemistry Principles and Modern Applications. Eleventh E. Toronto: Pearson; 2017.

13. Valerio LG, Cross KP. Characterization and validation of an in silico toxicology model to predict the mutagenic potential of drug impurities. Toxicol Appl Pharmacol. 2012;260(3):209-21.

14. Raies AB, Bajic VB. In silico toxicology: Computational methods for the prediction of chemical toxicity. Wiley Interdiscip Rev Comput Mol Sci. 2016;6(April):147-72.

15. Ji Z, Zhang L, Peng V, Ren X, McHale CM, Smith MT. A comparison of the cytogenetic alterations and global DNA hypomethylation induced by the benzene metabolite, hydroquinone, with those induced by melphalan and etoposide. Leukemia. 2010;24(5):986-91.

16. Yager JD. Mechanisms of estrogen carcinogenesis: The role of E2/E1quinone metabolites suggests new approaches to preventive intervention - A review. Steroids. 2015;99(Part A):56-60.

17. Loomis D, Guyton KZ, Grosse Y, El Ghissassi F, Bouvard V, Benbrahim-Tallaa $\mathrm{L}$, et al. Carcinogenicity of benzene. Lancet Oncol. 2017;18(12):1574-5.

18. Li J, Wang W, Moe B, Wang H, Li XF. Chemical and toxicological characterization of halobenzoquinones, an emerging class of disinfection byproducts. Chem Res Toxicol. 2015;28(3):306-18.

19. Shang Y, Zhang L, Jiang Y, Li Y, Lu P. Airborne quinones induce cytotoxicity and DNA damage in human lung epithelial A549 cells: The role of reactive oxygen species. Chemosphere. 2014;100:42-9.

20. Kazlauskas RJ, Bornscheuer UT. Enzyme
Catalytic Promiscuity: Expanding the Catalytic Action of Enzymes to New Reactions. Compr Chirality. 2012;7:46580.

21. Eder E, Hoffman C, Bastian H, Deininger C, Scheckenbach S. Molecular mechanisms of DNA damage initiated by $\alpha, \beta$-unsaturated carbonyl compounds as criteria for genotoxicity and mutagenicity. Environ Health Perspect. 1990;88:99106.

22. Dutta Gupta S, Rao GB, Bommaka MK, Raghavendra NM, Aleti S. Ecosustainable synthesis and biological evaluation of 2-phenyl 1,3-benzodioxole derivatives as anticancer, DNA binding and antibacterial agents. Arab J Chem. 2016;9:S1875-83.

23. LaiYY, Lien HM, Lin HW, Wang YJ, Chen LC, Yang DY, etal. Inhibition of anchorageindependent proliferation and $\mathrm{G} 0 / \mathrm{G} 1$ cell-cycle regulation in human colorectal carcinoma cells by 4,7-dimethoxy-5methyl-1,3- benzodioxole isolated from the fruiting body of antrodia camphorate. Evidence-based Complement Altern Med. 2011;2011.

24. Lai YY, Lien HM, Kuo PT, Huang CL, Kao JY, Lin H, et al. Study of the antiproliferative activity of 5-substituted 4,7-dimethoxy-1,3-benzodioxole derivatives of sy-1 from Antrodia camphorata on human COLO 205 colon cancer cells. Evidence-based Complement Altern Med. 2011; 1-8.

25. Shie PH, Wang SY, Lay HL, Huang GJ. 4,7-Dimethoxy-5-methyl-1,3benzodioxole from Antrodia camphorata inhibits LPS-induced inflammation via suppression of $\mathrm{NF}-\kappa \mathrm{B}$ and induction HO-1 in RAW264.7 cells. Int Immunopharmacol. 2016;31:186-94.

26. Cramer GM, Ford RA, Hall RL. Estimation of toxic hazard-A decision tree approach. Food Cosmet Toxicol. 1976;16(3):255-76.

27. Gfeller D, Michielin O, Zoete V. Shaping the interaction landscape of bioactive molecules. Bioinformatics. 2013;29(23):3073-9. 
28. D'Souza UM, Craig IW. Genetic Organization of the Serotonergic System. In 2010. p. 23-50.

29. Saito M, Yamagata T, Matsumoto A, Shiba Y, Nagashima M, Taniguchi S, et al. MAOA/B deletion syndrome in male siblings with severe developmental delay and sudden loss of muscle tonus. Brain Dev. 2014;36(1):64-9.

30. Cai Z, Hussain MD, Yan LJ. Microglia, neuroinflammation, and beta-amyloid protein in Alzheimer's disease. Int J Neurosci. 2014;124(5):307-21.

31. Sunami Y, Araki M, Kan S, Ito A, Hironaka Y, Imai M, et al. Histone acetyltransferase p300/CREB-binding proteinassociated factor (PCAF) is required for all-transretinoic acid-induced granulocytic differentiation in leukemia cells. J Biol Chem. 2017;292(7):2815-29.

32. Burcham PC, Thompson CA, Henry PJ. Acrolein and the lung: Chemical, molecular, and pathological aspects. Adv Mol Toxicol. 2010;4(C):1-36.

33. Kawasaki T, Kawai T. Toll-like receptor signaling pathways. Front Immunol. 2014; Sep 25;5:461.

34. Magnusson LU, Lundqvist A, Karlsson MN, Skålén K, Levin M, Wiklund $\mathrm{O}$, et al. Arachidonate 15-lipoxygenase type B knockdown leads to reduced lipid accumulation and inflammation in Atherosclerosis. PLoS One. 2012;7(8):e43142.

35. Dimitrov L, Hong CS, Yang C, Zhuang Z, Heiss JD. New developments in the pathogenesis and therapeutic targeting of the IDH1 mutation in glioma. Int J Med Sci. 2015;12(3):201-13.

36. López-Vicario C, Rius B, Alcaraz-Quiles J, García-Alonso V, Lopategi A, Titos E, et al. Pro-resolving mediators produced from EPA and DHA: Overview of the pathways involved and their mechanisms in metabolic syndrome and related liver diseases. Eur J Pharmacol. 2016;785:13343.

37. Cole BK, Lieb DC, Dobrian AD, Nadler JL. 12- and 15-Lipoxygenases in Adipose Tissue Inflammation. Prostaglandins Other Lipid Mediat. 2013;104-105:8492.

38. Neighbour H. Mechanisms of aspirinintolerant asthma: Identifying inflammatory pathways in the pathogenesis of asthma. Int Arch Allergy Immunol. 2014;163(1):1-2.

39. Balaban S, Shearer RF, Lee LS, van Geldermalsen M, Schreuder M, Shtein $\mathrm{HC}$, et al. Adipocyte lipolysis links obesity to breast cancer growth: adipocytederived fatty acids drive breast cancer cell proliferation and migration. Cancer Metab. 2017;5(1). 